\title{
Egy Karinthy-karcolat alluzív fölépítése: A szürkék hegedöse
}

1. A beszédtevékenység folyamán a beszélők föltételezik, hogy a társalgásban részt vevők tisztában vannak közös, de meg nem nevezett ismeretekkel, körülményekkel, tapasztalatokkal. Emellett a közös nyelv, a beszédhelyzet ugyancsak segíti egymás megértését, akkor is, ha némelyik (vagy számos) megnyilatkozás ténylegesen nem is nevezi meg a gondolatok (föltehető) teljességét. Általánosságban az efféle jelenség célzásnak, allúziónak tartható, vagyis a fölösleges terjengősséget (is) szabályozó megoldásnak (lásd Fónagy 1972). Ez az elhagyás (detrakció) a kifejezés stílusa szempontjából erény, de hiba is lehet. A célzást, allúziót mint gondolatalakzatot tartja számon a retorika. Szűkebb értelemben valamely közismert kifejezés perifrasztikus átírásaként, variációjaként (Szabó G.-Szörényi 1988: 170; Hangay 2010). A célzás tucatnyi, föként versekböl való példáját mutatja be Eöry 2008: 74-7.

Az allúzió sikere, hatásossága a beszédfolyamatban részt vevők valamilyen fokú érdekeltségétől is függ. Ez jól érvényesül a társadalmi-politikai élet (mondhatni) minden jelenségére való utalások révén. A szépirodalom szövegvilágában ugyanez a helyzet. Mindazokra a külső és belső szövegjellemzőkre lehet célozni, amelyek a tartalomra vagy a nyelvi megformáltságra vonatkoznak. A megnyilatkozások vagy beszédművek, illetőleg szövegművek tartalma a célzás(ok) révén a más hasonló nyelvi anyagok tartalmára vonatkoznak. Ezek a vonatkozások valamilyen gondolkodásmódbeli összefüggésekkel lehetnek kapcsolatban. Az összefüggések minemüsége az éles ellentéttől a hasonlóságon keresztül az azonosságig rendkívül széles körü lehet. Fónagy Iván lexikoncikkében ezért szerepel az allegória, az enigma, az anagógé, az eufémizmus, az aposziopézis, a quidproquo, a szójáték, a szólás, az evokáció, továbbá a szóképformájú célzások és még az archaizálás megemlítése is. Ha a célzás olyan kapcsolatra hívja föl a figyelmet, amelyik az általános ismeretektől, a szokásos gondolkodásmódtól valamilyen mértékben eltér, kisebb-nagyobb hatást vált(hat) ki. Az eltérést a befogadó észlelheti, értékelheti, igaznak vagy hamisnak veheti, lehetséges, hogy humorosnak tartja. Az allúziót az áthallás müszóval nevezi meg és értelmezi mint szövegek stílusa közötti kapcsolatot stilisztikakönyvében Szikszainé Nagy Irma (2007: 169, 185), valamint részletezi és példákkal mutatja be, külön kitér az úgynevezett „tréfás áthallásokra” - példát éppen Karinthytól idéz: „A férjem gondolkodik, tehát vagyok."

A szürkék hegedőse - A közgazdasági miniszter beszámolója a képviselöház 1913. szept. 20. üléséről címet adott egyik karcolatának ${ }^{1}$ Karinthy Frigyes (1958). Az írás ironikus-humoros volta a címben megjelenő, az irodalomból való téma parlamenti ügyként kezeléséből származik. A karcolat irodalmi mű gyanánt egy lehetséges világ történése(i)t mondja el a benne lévő ábrázolt tárgyiasságokkal egyetemben, de allúzióinak nagy része a valóságos világ dolgaira vonatkozik. E tekintetben megjegyzendő, hogy Hatvany Lajos nem volt miniszter.

1 Ugyanezzel a címmel még egy rövidebb írása van Karinthynak, amelyiknek témája és történései szintén egyeznek. Ez az írás a többlapos Fantázia és Vidéke címü, Karinthy által kitalált újságban van a Képviselöház rovatban (Karinthy 1984: 481, 492). 
A szöveg az idézett kiadás helyesírása szerint az alábbi; []-ben vannak jelezve azok az célzások, amelyeknek a szöveg értelmi fölépítésében lényeges(ebb) szerepe van.

A szürkék hegedőse [i]

A közgazdasági miniszter beszámolója a képviselőház 1913. szept. 20. üléséről [iii]

Tisztelt Ház!

Van szerencsém ezennel beszámolómat letenni a Ház asztalára, vonatkozólag Hatvany Lajos [2] képviselő úrnak múlt ülésen a szürkék hegedőséről [i $=1]$ szóló interpellációjára.

Mint tudjuk, a szürkék hegedősének égető és sürgető kérdését először doktor [3a] Ady Endre [3b] közgazdász [3c] vetette föl Repülj, hajóm [4] címü szociálfilozófiai értekezésében [5], melynek befejező szakaszában a következő paragrafus szorítkozik e tárgyra:

Én nem leszek a szürkék hegedöse,

Hajtson szentlélek, vagy a kocsma göze.

Repülj, hajóm, ne félj, hajóm,

Én nem leszek a szürkék hegedöse.

Az interpelláció elmondja, hogy a közoktatásügyi minisztérium e paragrafus alapján tudomásul vette, hogy nevezett egyén kijelentése következtében a szürke-hegedősi állás [6a], mint államhivatal [6b], betöltetlennek vehető. Önmagától, úgymond, s fenyegetően alakult ki azonnal a kérdés: ki lesz hát akkor a szürkék hegedőse? Ez az állapot sokáig tarthatatlannak látszott, jelentkező nem akadt, és a kormány semmit sem tehetett az abnormis helyzet megszüntetésére mely hovatovább egész Európa figyelmét s megbotránkozását közviszonyainkra fordítani alkalmas lehetett. Mert, ugyebár, hogy néz ki egy ország, ahol a szürkéknek nincs hegedőse? Az üresedés sokáig stagnált. Mint költségvetésünkböl [7a] kimutathatjuk, a minisztérium még egyszer megkereste Ady Endre urat, hogy lemondását fenntartja-e, s mivel okolja meg? Válaszából, melyet a Nyugat hasábjain [8] közvetített, annyit állapítottunk meg, hogy közhajózási viszonyainkkal nincs megelégedve, repülö hajók létesítését tartja szükségesnek, mely kívánságát költségvetésünk [7b] mai állása mellett nem teljesíthettük. Azonkívül részletesen foglalkozott a zeneoktatással [9a], kifogásolta, hogy különböző színű zongorákon tanítják az ifjúságot, ami nem jó a szemnek, s javasolta a fekete zongora [9b] hivatalos elrendelését. Végre hivatkozott arra, hogy, mint a Halál rokona [10], jobb állásra tarthat igényt - erre vonatkozólag meg kell jegyeznünk, hogy rokoni alapokat kormányunk sohasem vett tekintetbe [11], s különben is nem volt kimutatható, nevezett milyen rokonságban van az említett családdal [12].

Ezekután, nehogy effajta zavarok újra fölmerülhessenek, a kormány indíttatva érezte magát, hogy a szürkék hegedősi állását külön s határozott formában szervezze, s ez úton hirdessen pályázatot az állás hivatalos formában történő betöltésére.

A szürkék hegedőse, mint hivatal és jelleg, ezentúl tehát a közoktatásügyi minisztérium reszortjába tartozik. Külön helyiséget állapítottunk meg a minisztérium helyiségei közt, második emelet, kilenc jobbra, a toalett-helyiség mellett [13]. 
A szürkék hegedőse itt fogad, reggel 9-12-ig minden ügyben, mely szigorúan a szürkék érdekeivel s kívánságaival foglalkozik, különös tekintettel a hegedőlésre. A szürkék, akik hegedőltetni akarnak maguknak, kívánságukat bélyeges kérvény alakjában adják be, két nappal a kérdéses látogatás előtt, mikor is papírjaik s oltási bizonyítványuk bemutatása után a szürkék hegedőse megfelelő hegedőlésben részesíti őket [14]. Kivételes alkalmakkor, s ha nagyon sok a jelentkező, du. 4-5-ig is eszközölhető hegedőlés járószürkék [15] részére. Akut szürkéket a hegedölési hivatal kórházi kezelésre [16a] fel is vehet. A szürkéket hegedőlés előtt dezinficiálják [17] és kezelik [16b].

Örömmel jelentheti a kormány, hogy tervbe vett még néhány hegedősi hivatalt. A közeljövőben dől el, hogyan szervezzük a pirosak, kékek és zöldek [18a] hegedősi állását. A piros-fehér-zöldek [18b] és átmeneti színüek hegedőse is meglesz. A feketék hegedősére és a sárgák hegedősére [19] vonatkozó javaslatokat átküldték az osztrák képviselőháznak [20].

2. A szürkék hegedőse $[(i)=1]$ célzás Ady Endre versére - Új vizeken járok -, pontosabban a költemény utolsó szakaszára, amely egyúttal a költő 1906. évi Új versek kötetét is lezárja, és amelyet Karinthy később idéz is. A Karinthy-cím az Ady-vers utolsó sorából van kiemelve, azzal egyezik, ezenkívül azzal is az Ady-címekre utal, hogy azok legtöbbje - éppen az Új versek óta - háromszavas (vö. J. Soltész 1965: 183). A címben lévő hegedős szó önmagában archaikus (OklSz. 1544: „Attam a hegedősöknek es az yatekosoknak"), illetöleg nyelvjárási szóalakja miatt is (ÚMTsz. hegedős) célzás [i] valamely bizonytalan dologra, amely a szóalak szokatlanságával függ öszsze. Ez az egész szövegen végighúzódó szóhasználat nemcsak a témaszó(szerkezet) szerepkörét tölti be, hanem életben tartja a tématárgynak különösségét is, amelyik tulajdonság a valós világ Adyjának költői nyelvében ismeretes: a népnyelvi vagy régies elemek beépítése (lásd Kovalovszky 1965: 54-5). A karcolat alcíme tartalomelmondó címközlemény: A közgazdasági miniszter beszámolója a képviselöház 1913. szept. 20. üléséről [ii]. Az alcím mint szövegkörnyezet magyarázatot ad az [i] allúzióra, ugyanis lehetséges, hogy az olvasó ismeretei kiterjednek minderre, sőt arra is, hogy abban a lehetséges világban - amelynek ábrázolt tárgyiasságai a való világéinak felelnek meg (Ingarden 1977: 227) - kicsi a valószínüsége annak, hogy a miniszter ne köznyelvi szavakat használjon a képviselőházban.

A Karinthy-szövegmü a (magyar) parlamentben felszólalók szokásos megszólításával kezdődik (Tisztelt Ház!). Az országgyülés korabeli nyelvhasználatát az egyes szavak előfordulásának gyakorisága is jelzi, Karinthy e szavak használatával is tudja ábrázolni annak a szövegfajtának a stílusát, amely egészében hivatali módozatú. Nemes Zoltán (1933) szóstatisztikája szerint például a kormány főnév 231 előfordulással szerepel a korabeli parlamenti nyelvben, Karinthy négyszer írja bele a tárcába. Néhány további összehasonlítás a parlamenti nyelv, illetőleg a tárcában elöforduló szavak között: állam 180 : 1, úr 277 : 2, képviselö 167 : 1 +2, képviselöház, ország 157 : 1, javaslat $120: 1$, állás $51: 6$, figyelem 31 : 1, megállapit $49: 2$, költségvetés $45: 2$, minisztérium $26: 4$. Ezek mellett más hivatali nyelvhasználatúak is szere- 
pelhetnek részben mint témaszavak (hivatal[os], paragrafus, zeneoktatás), részben mint olyan köznyelvi szavak, amelyek használata több stílusrétegben is előfordulhat. Már a miniszteri beszéd első szövegmondata megfelel nemcsak szóhasználat, hanem stílusforma szempontjából is annak a szövegfajtának, amely egészében hivatali módozatú: Van szerencsém ezennel beszámolómat letenni a Ház asztalára, vonatkozólag Hatvany Lajos [2] képviselö úrnak múlt ülésen a szürkék hegedőséről szóló interpellációjára. Hatvany Lajos (1880-1961) szerepeltetése nyilvánvaló célzás, ő a Nyugat mecénása, Ady barátja, támogatója, aki 1911-ben megvált a folyóirattól, ugyanis Osváttal ellentétbe került. Karinthy Frigyes (1928) majd kiáll Hatvany Lajos mellett annak pere idején, ami jelzés Karinthynak a rá vonatkozó véleményéről (is). (A való életből származó írói nevekről és hatásukról Karinthy egyes müveiben lásd Vácziné Takács 2018: 59 et passim.) A karcolat címközleménye így célzásnak minősíthető, hiszen 1913-ban már Ady valójában nem a „szürkék hegedőse”, vagyis nem a jelentéktelenek költője, ha lehet így értelmezni a kifejezést, hanem a Vér és arany, Az Illés szekerén, a Szeretném, ha szeretnének, a Minden-Titkok versei kötetei után ebben az évben jelenik meg A Magunk szerelme.

A szövegmü folytatása ezután nyíltan utal Adyra mint ábrázolt tárgyiasságú személyre (is): Mint tudjuk, a szürkék hegedösének égetö és sürgetö kérdését elöször doktor [3a] Ady Endre [3b] közgazdász [3c] vetette föl Repülj, hajóm [4] címü szociálfilozófiai értekezésében - továbbá közli a vers utolsó szakaszát. Minthogy a Repülj, hajóm a karcolatban már említett és idézett ,értekezés”-re vonatkozik, így könnyen azonosítható az $[i]$ jelzetủ célzással, vagyis a Karinthy-írás címének alluzivitásával. A szociálfilozófiai értekezés [5] kifejezésben a jelzö, illetőleg a szociálfilozófia 'társadalombölcselet' szó használatosabb volt, mint mostanában (lásd Juhász 1947-1948). A MNSz.-ban három adattal szerepel (öt van a szociálfilozófiára), vagyis az elöfordulás (mai kisebb száma) nagyobb hírértékkel és hatással jár, mint az Karinthynál volt. Ady versének ilyetén jellege természetesen nagyítása a szövegmüben föllelhető társadalmi-szociológiai vonatkozásoknak: „új, félelmetes Élet”, szentlélek”, „kocsmagőz”.

Ady a debreceni jogakadémián (!) csupán néhány vizsgát tett le, tehát a doktori cím [3a] említése a valós világban nem érvényes, ez nagyítás, hiperbola, a szövegmüben viszont miniszteri beszámoló hivatali nyelvezetéhez illő gondos megnevezés, amelyik sejteti a szóban forgó ügy komolyságát. A közgazdász minősítés [3c] szintén célzás: Adynak egyik versfüzérére - A magyar Ugaron - mint (mező)gazdasági szakírásokra tekint Karinthy. E versciklus jelentőségét nemcsak Karinthy látja itt és most, később az irodalomtörténetírás hasonlóképpen vélekedik (lásd Király 1970: I, 144-216). A karcolat ábrázolt tárgyiasságának megfelelő világán kívül mindkét titulus (a doktor és a közgazdász) ironikus.

Az értekezésnek emített Repülj, hajóm [4] cím ugyancsak célzás: kiragadott szerkezet a valós Ady-versből. Ez az értekezés - amelyik egyébként szintén nagyítás a való világban mint szövegfajta a tudományos, az allúziós említésü Repülj, hajóm pedig költői-írói eredetü. Így az író ellentétet (antitézist) hozott létre, amely ironikus-humoros képzettársítást kelthet. Ugyanilyen a fölépítés és a hatáskeltés az értekezésnek mondott befejező szakasz paragrafus '(törvény)cikkely' megnevezésével, hiszen a 'versszak'-ra nem szokás a paragrafus szót használni. 
A karcolat a költemény idézésével folytatódik, majd az országgyülési beszédmódozatnak megfelelve használja az ironikus hangnemet, felnagyítva a helyzetet: a „szürke-hegedősi állás, mint államhivatal, betöltetlennek veheto”” (vö. ÉrtSz. hivatal 4.: 'hivatalos állás, tisztség'), „hovatovább egész Európa figyelmét s megbotránkozását közviszonyainkra fordítani alkalmas lehetett. Mert, ugyebár, hogy néz ki egy ország, ahol a szürkéknek nincs hegedőse?” Az íráskép - a két dőlő betüs szó - az ügy immár állami szempontból való fontosságára utal [6].

A minisztérium megkísérli orvosolni az állapotot: Mint költségvetésünkböl [7a] kimutathatjuk, a minisztérium még egyszer megkereste Ady Endre urat, hogy lemondását fenntartja-e, s mivel okolja meg? Válaszából, melyet a Nyugat hasábjain [8] közvetített, annyit állapítottunk meg, hogy közhajózási viszonyainkkal nincs megelégedve, repülö hajók [9] létesitését tartja szükségesnek, mely kívánságát költségvetésünk [7b] mai állása mellett nem teljesithettük. Ebben a részben a Nyugat folyóiratra való allúzió Adynak a valós világban meglévő kapcsolatára vonatkozik, másrészt kissé ironikus, minthogy nem a Nyugat oldalain szokás minisztériumi megkeresésekre válaszolni.

A Mint költségvetésünkböl [7a] kimutathatjuk arra célozhat, hogy a karcolat írója a kormány tevékenységét is kifogásolhatónak látja, hiszen bizonyosan fölösleges kiadásokra lehet gondolni „Ady Endre úr” megkeresésével kapcsolatban, ennek pedig ellentmond a költségvetés [7b] „mai állása”, amint a miniszter kijelentéséből tudhatni.

Az olvasó által már ismeretes versszövegböl a repülö hajók létesítésének követelése már a Karinthy-szövegmü belső allúziója a korábbi Repülj, hajóm alapján, és egyúttal humorba fordítása is. A köznapi értelemben vett hajók repülése olyan hatást keltő ellentét (contrapositum), amely „Ady Endre úr” gondolkodásának zavarosságára vall. Az efféle véleményekre az Így írtok ti egyik Ady-parafrázisa is rájátszik Az utolsó mosoly címü vers ismétléseire célozva: „Hát maga megbolondult, | Hát maga megbolondult, | Hogy mindent kétszer mond, kétszer mond?" (A törpe-fejüek, Karinthy Frigyes 1959: 18-9; vö. Lörincz 2011).

A miniszteri beszámoló kitér arra is, hogy a „nevezett egyén” részletesen foglalkozott a zeneoktatással [9a]. A fekete zongora (Ady Endre 1961: 81) szövege tartalmaz olyan részt, amelyik ironikusan játéktechnikának is fölfogható (,mestere tépi, cibálja"); ugyanakkor ez a célzás elörevetíti az ezután következő allúzió(ka)t. Ezzel kapcsolatban téves tudáson nyugszik a miniszter által Adynak tulajdonított állítás, amely szerint: különböző színü zongorákon tanitják az ifjúságot, ami nem jó a szemnek, s javasolta a fekete zongora [9b] hivatalos elrendelését. Itt kimondottan az egyébként hírhedtté vált $A$ fekete zongorára vonatkozik az utalás. A költemény értékelése, befogadása még Ady méltatói számára sem ment könnyen, szinte szólássá vált Ignotus [Veigelsberg Hugó] kijelentése: „Akasszanak föl, ha értem” (vö. Vezér 1969: 204; Király 1970. I: 480-4). „Ady Endrét nem érteni, hanem csodálni és szeretni kell" - írta Karinthy Frigyes (1909: 562), Karinthy véleménye mint elözetes tudás hozzájárul(hat) az egész karcolat céljához, vagyis ahhoz, hogy a(z irodalmi) hivatalosság látszódjék hibásnak.

A miniszteri beszámoló alluzív célzásokkal marasztalja el az interpellálót: Végre hivatkozott arra, hogy, mint a Halál rokona [10], jobb állásra tarthat igényt-erre 
vonatkozólag meg kell jegyeznünk, hogy rokoni alapokat kormányunk sohasem vett tekintetbe [11], s különben is nem volt kimutatható, nevezett milyen rokonságban van az emlitett családdal [12]. A Halál rokona ugyancsak az imént említett Ady-kötet verse (1961: 72), amelyik Az Új vizeken járok mellett ugyancsak nevezetes költemény; a költőnek a halál egyik jellegzetes költői motívuma (Király 1970, I: 462-80). Emellett a „rokoni alapokat” tekintetbe nem vevő kormányt képviselő miniszter elszólja magát: nem volt kimutatható, nevezett milyen rokonságban van az említett családdal. Vagyis: ha a rokonságot ki lehetett volna mutatni, esetleg más megítélése lehetne a korábban megnevezett egyénnek, ami megint csak a kormány vagy a miniszter működésének rejtett bírálataként fogható föl az előfeltevések elmélete szerint is. Ugyanis minden megnyilatkozás (mondat) nem csupán az explicite kimondott jelentésből áll, hanem hozzátartozik az is, ami szemantikailag vagy logikailag ebből a jelentésből következik (Kiefer 1983: 9). Karinthy itt közvetett célzást tesz: ki akarták mutatni a rokonságot, holott az előző kijelentésekből tudható, hogy erre nincsenek tekintettel. A miniszter kijelentése tulajdonképpen elszólás, saját (és a kormány) szavahihetőségét ingatja meg, hiszen a pszichológiában 'váratlan, nem megszokott tartalmú(, humoros) megszólalás' az elszólás (Nszt.), (vö. Fónagy 1999: 240).

A miniszter bejelentése szerint hivatalos útra terelödött a szürkék hegedősének ügye. Állami hivatalt szerveznek: A szürkék hegedőse, mint hivatal és jelleg, ezentúl tehát a közoktatásügyi minisztérium reszortjába tartozik. Külön helyiséget állapítottunk meg a minisztérium helyiségei közt, második emelet, kilenc jobbra, a toalett-helyiség mellett [13]. A komoly hivatalosság azonban önmagát rombolja azzal, hogy az új hivatal toaletthelyiség mellett való elhelyezéséről szól, hiszen a szürkék hegedőse hivatalának alacsonyítása, ennek a meiózisnak révén ironikussá válik a miniszter tájékoztatása. A ,toalett-helyiséggel” van laza kapcsolatban Karinthy magánéletének egyik epizódja (Büky 2017).

A karcolat ezután részletezi az új hivatal rendjét: A szürkék hegedöse itt fogad, reggel 9-12-ig. „A formák és formulák kész keretet adnak a komikum ábrázolására” - írta Bergson (1968: 659), Karinthy ezt meg is teszi: kiderül, hogy a rendszerben a bürokrácia szokásos eljárási módjainak bősége mellett („,bélyeges kérvény”, „oltási bizonyítvány" stb.) a hivatalban az arra jogosultakat a szürkék hegedöse megfelelö hegedölésben részesiti [14]. Ez a célzás az elhegedüli valakinek a nótáját szólásra vonatkozik, amely rendszerint fenyegetésként használva 'elver, elnáspángol; ellátja a baját' jelentésü (O. Nagy 1966: 499, n282).

Eddig a karcolatban nem esett szó arról és célzás sem volt rá, hogy kik azok a szürkék, akik miatt „Hatvany Lajos képviselő úr” és „,doktor Ady Endre közgazdász” fellépett. Először csupán arra van célzás, hogy valamiféle betegség sújthatja őket, ez a járóbeteg ( fekvőbeteg) köznyelvi szerkezet(ek) alapján érthető rá a járószürke fönévre, amelyik ma kétszavas szerkezet (vö. ÉKsz. ${ }^{2}$ járóbeteg-rendelés): Kivételes alkalmakkor, s ha nagyon sok a jelentkezö, du. 4-5-ig is eszközölhetö hegedölés járószürkék részére [15]. A betegség nem múlik könnyen, hevennyé (Nszt. akut) válhat: Akut szürkéket a hegedölési hivatal kórházi kezelésre [16a] fel is vehet. Ezután a szürkék fertőtlenítése [17a], további orvoslása következik: A szürkéket hegedőlés elött dezinficiálják [17b] (Nszt. dezinficiál 'fertőtlenít') és kezelik [16b] (ÉrtSz. kezelés 
4.: „Orvosi gondozás, gyógyító eljárás, gyógyítás, gyógykezelés”; kezel 3.: „〈beteget, betegséget, sebet〉 rendszerint hosszabb v. ismételt, rendszeres orvosi eljárással gondoz, gyógyulását segíti"). A fertőtlenítésre vonatkozó célzások a betegség járványszerü jellegére utalnak, vagyis nem elmebetegségre, mindenesetre a korábbi repülö hajók, a zongorák színei, továbbá a ki nem mutatható, a Halállal való rokonság éppenséggel mind arra utal, hogy mégis elmezavarról lehet szó. Ugyanakkor a miniszter és a kormány éppen a társadalomszervezési rend alapján cselekedik: Örömmel jelentheti a kormány, hogy tervbe vett még néhány hegedösi hivatalt. A közeljövöen döl el, hogyan szervezzük a pirosak, kékek és zöldek [18] hegedösi állását. A piros-fehér-zöldek [19] és átmeneti színüek hegedöse is meglesz. A magyar, úgynevezett nemzeti színek a magyarságát folyton hangoztató egyes politikai párt(ok)ra és hívei(k)re vonatkoz(hat)nak. A karcolat záró része ezzel szemben az ország, az állam politikai állapotára céloz. A szürkék mellé fölsorakoztatott egyéb színek az abnormitásból a fekete-sárga révén a magyar parlament (és voltaképp az ország) Ausztriával való szövetségre céloznak: A feketék hegedősére és a sárgák [20] hegedösére vonatkozó javaslatokat átküldték az osztrák képviselöháznak [21]. Ezek a színek szemiotikai értelemben vett jelek. Az Osztrák-Magyar Monarchia ugyan csak a külügy, a hadügy és a pénzügy tekintetében volt összekötve a schwarz-gelb világgal, a hegedősökre vonatkozó javaslatok odaküldése arra céloz, hogy a magyar kormány egyedül nem tud vagy mer dönteni, aminek ironikussága a magyar politikai élet vezetőinek szól.

A célzásoknak egyik fele a valóságos világ dolgaira vonatkozik, másik fele a lehetséges világéira is $(11+11)$. Ezeknek külön-külön a kétszerese (22) az olyan az ábrázolt tárgyiasságoknak a száma, amelyek meg vannak jelenítve a szövegmű lehetséges világában.

Ez nyilván annak a következménye, hogy célzásoktól függetlenül érvényesül a karcolat mint szövegmű kohéziós fölépítése, amely már a címadással mozgósítja a felidézendő ismereteket, amelyek révén létrejön az értelmi folyamatosság, vagyis a koherencia alapja. Erre a szövegmü lehetséges világában érvényesülő allúziók rakódnak, amelyek egy része a valóságos világbeli, egy része pedig mindkét helybeli dolgok referenciáját teremtik meg, és éppen ezek a referenciák egymás közötti viszonyai adják az allúziók hatását.

\begin{tabular}{|c|c|c|}
\hline a valóság & $\begin{array}{c}\text { A célzások érvényesülése } \\
\text { a szövegmú lehetséges } \\
\text { világában }\end{array}$ & mindkét hely \\
\hline 1 [Hatvany Lajos] & 1 & 1 \\
\hline \multirow[t]{2}{*}{2 (= i) [szürkék hegedőse] } & 2 (= $i)$ [szürkék hegedőse] & $2(=i)$ [szürkék hegedőse] \\
\hline & 3a [doktor] & \\
\hline \multirow[t]{2}{*}{ 3b [Ady Endre] } & 3b [Ady Endre] & $\mathbf{3 b}$ [Ady Endre] \\
\hline & 3c [közgazdász] & \\
\hline 4 [Repülj, hajóm] & 4 [Repülj, hajóm] & 4 [Repülj, hajóm] \\
\hline
\end{tabular}




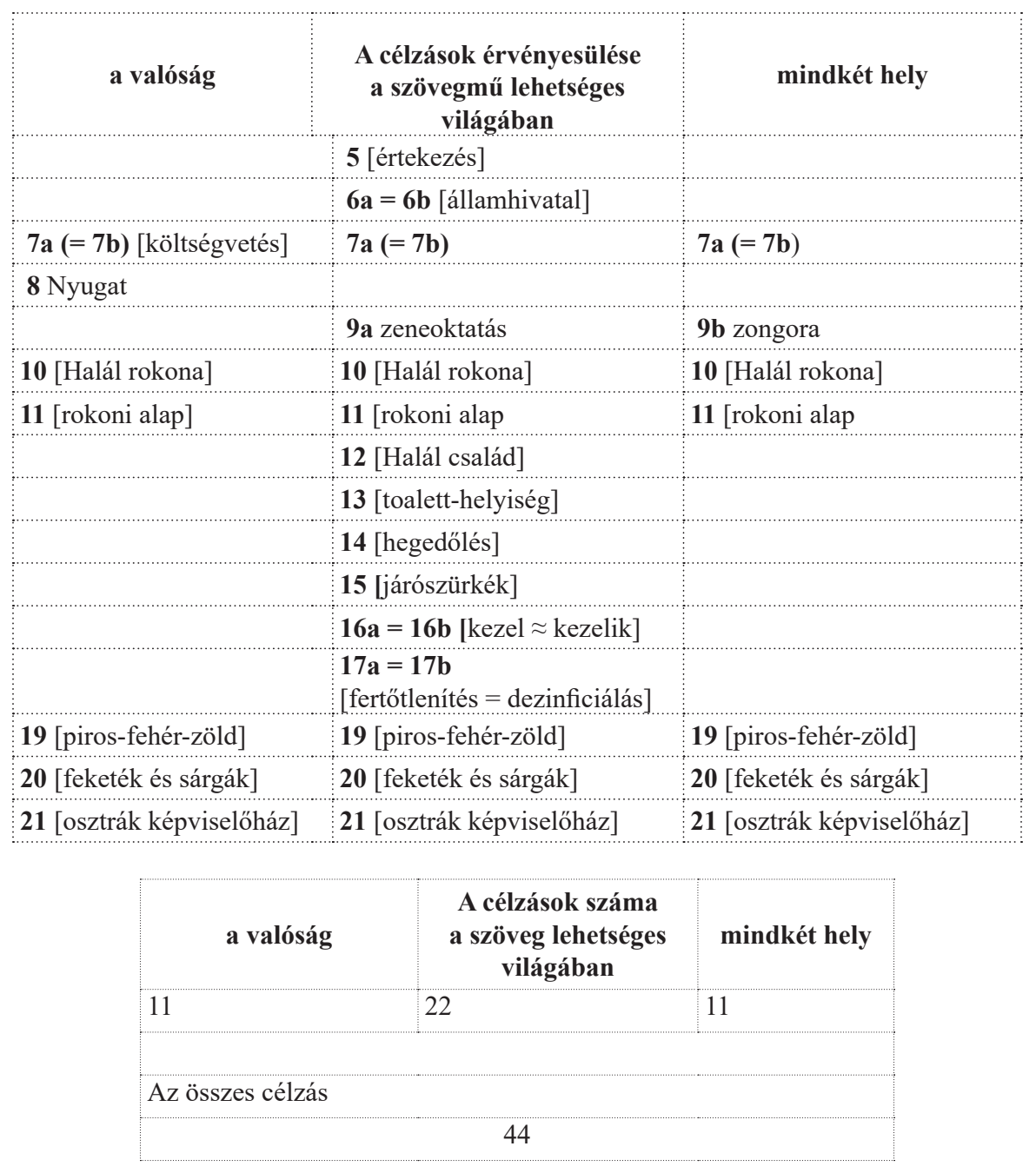

3. Karinthy karcolatának egésze humorosnak tartható, lehetséges világában is „abnormis helyzet" a parlamenti beszámoló. A humor mint esztétikai minőség, amely (valószínúleg) az intelligencia velejárója, amely képesség - R. L. Thorndike szerint - a verbális és áttételes, szimbolikus és elvont fogalmak értelmi földolgozására (vö. Atkinson 1999²: 216-9). Erre a képességre van szüksége az olvasónak, hogy A szürkék hegedősének allúzióit megértse, és a szövegkörnyezet lehetséges világában, illetőleg a való világra alkalmazva megfelelő módon értékelje. 


\section{SZAKIRODALOM}

Ady Endre 1961. Összes verse. Szépirodalmi Könyvkiadó, Budapest.

Atkinson, Rita Loyd et al. 1999². Pszichológia. Osiris Kiadó, Budapest.

Bergson, Henri 1968. A nevetés. Gondolat Kiadó, Budapest. (Eredetije: 1914.)

Büky László 2017. „Merdre!”-től az „örök anyag”-ig. Forrás 49/9: 105-9.

ÉKsz. ${ }^{2}=$ Magyar értelmező kéziszótár. Főszerk. Pusztai Ferenc. 2. átdolgozott kiadás. Akadémiai Kiadó, Budapest, 2003.

ÉrtSz. = A magyar nyelv értelmező szótára 1-7. Főszerk. Bárczi Géza - Országh László. Akadémiai Kiadó, Budapest, 1959-1962.

Fónagy Iván 1972. [A] célzás. In: Király István (főszerk.): Világirodalmi lexikon. Akadémiai Kiadó, Budapest, 1-13.

Fónagy Iván [1999]. A költői nyelvröl. Corvina, é. n., h. n. [Budapest.]

Hangay Zoltán 2010. [A] célzás ${ }^{1}$. In: Adamik Tamás - Balázs Géza - Nemesi Attila László 2010. [A] célzás ${ }^{1}$. In: Adamik Tamás (föszerk.): Retorikai lexikon. Kalligram Kiadó, Pozsony.

Ingarden, Roman 1977. Az irodalmi müalkotás. Gondolat, Budapest. (Eredetije: 1951.)

Juhász Vilmos föszerk. 1947-1948. Révai kétkötetes lexikona 1-2. Révai Irodalmi Intézet, Budapest.

Karinthy Frigyes 1909. Ady Endréröl. Nyugat 2: 10-1; 560-2. [1909. június 1.]

Karinthy Frigyes 1928. Hazaszeretetröl és hazaszerelemről. Pesti Napló 79/109: 10.

Karinthy Frigyes 1958. A szürkék hegedőse. In: Az egész város beszéli 1-4. Szépirodalmi Könyvkiadó, h. n. [Budapest.] 1: 476-8.

Karinthy Frigyes 1959. Így irtok ti. Szépirodalmi Könyvkiadó, Budapest.

Karinthy Frigyes 1984. Szavak pergőtüzében. Szépirodalmi Könyvkiadó, Budapest.

Kiefer Ferenc 1983. Az elöfeltevések elmélete. Akadémiai Kiadó, Budapest.

Király István 1970. Ady Endre 1-2. Magvető Kiadó, Budapest.

Kovalovszky Miklós 1965. Egy Ady-vers világa-Új, tavaszi sereg-számla. Magyar Nyelvtudományi Társaság, Budapest. (MNyTK. 111. sz.)

Lőrincz Julianna 2011. Karinthy-paródiák és Ady-versek funkcionális stilisztikai összevetése. Alkalmazott Nyelvészeti Közlemények 6/1: 147-54.

Nemes Zoltán 1933. A magyar parlamenti nyelv leggyakoribb szavai. Szeged Városi Nyomda és Könyvkiadó Rt., Szeged. (Az Egységes Magyar Gyorsírás Könyvtára 57. sz.)

O. Nagy Gábor 1966. Magyar szólások és közmondások. Gondolat Kiadó, h. n. [Budapest.]

Nszt. = A magyar nyelv nagyszótára 1-. Főszerk. Ittzés Nóra. MTA Nyelvtudományi Intézet, Budapest, 2006-.

OklSz. = Magyar oklevélszótár. Régi oklevelekben és egyéb iratokban elöforduló magyar szók gyüjteménye. Pótlék a Magyar nyelvtörténeti szótárhoz / Lexicon vocabulorum Hungaricorum. In diplomatibus aliisque scriptis quae reperiri possunt vetusto. Gyüjt. Szamota István. Szótárrá szerk. Zolnai Gyula. Hornyánszky, Budapest, 1902-1906.

J. Soltész Katalin 1965. A címadás nyelvi formái a magyar irodalomban. Magyar Nyelvőr 89: 174-87.

Szabó G. Zoltán - Szörényi László 1988. Kis magyar retorika. Tankönyvkiadó, Budapest.

Eőry Vilma 2008. [Az] allúzió. In: Szathmári István (főszerk.): Alakzatlexikon. Tinta Könyvkiadó, Budapest.

Szikszainé Nagy Irma 2007. Magyar stilisztika. Osiris Kiadó, Budapest.

ÚMTsz. = Új magyar tájszótár 1-5. Főszerk. B. Lőrinczy Éva. Akadémiai Kiadó, Budapest, 1979-2010. 
Vácziné Takács Edit 2018. Az írói névadás sajátosságai Karinthy Frigyes müvei alapján. ELTE BTK Magyar Nyelvtörténeti, Szociolingvisztikai, Dialektológiai Tanszék, Budapest. DOI: https://doi.org/10.26546/4890065

Vezér Erzsébet 1969. Ady Endre élete és pályája. Gondolat Kiadó, Budapest.

\author{
Büky László \\ ny. egyetemi tanár \\ Szegedi Tudományegyetem \\ Magyar Nyelvészeti Tanszék \\ https://orcig.org/0000-0002-4960-9445
}

\title{
SUMMARY
}

Büky, László

\section{The allusive structure of a sketch by Frigyes Karinthy}

In the possible world of Karinthy's sketch A szürkék hegedöse 'A Fiddler for the Drab Ones', parliamentary diaries constitute a source of humour. Humour as an aesthetic quality, possibly accompanying intelligence, is an ability to mentally process verbal and transferred messages involving symbolic and abstract notions. The reader has to have such ability in order to comprehend the allusions in A szürkék hegedöse, apply them to phenomena of the real world and appreciate them appropriately.

Keywords: allusions, represented objectivity, nonsense text, humour, Frigyes Karinthy 